\title{
Degradation of mortar render façades: case study in residential buildings
}

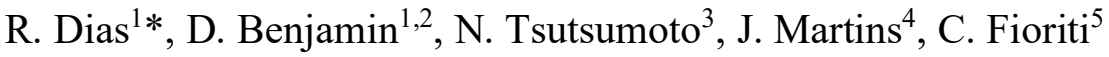 \\ *Contact Author: rdias07@live.com
}

${ }^{1}$ Departamento de Engenharia Civil, Faculdade de Engenharia de Ilha Solteira, Universidade Estadual Paulista-
FEIS/UNESP, Ilha Solteira, Brasil.
${ }^{2}$ Instituto Superior Politécnico do Huambo, Universidade José Eduardo dos Santos, Huambo, Angola.
${ }^{3}$ Instituto Federal de Educação, Ciência e Tecnologia de São Paulo, Campus Avançado Ilha Solteira, SP, Brasil
${ }^{4}$ Universidade Estácio de Sá, Ribeirão Preto, Brasil.
${ }^{5}$ Faculdade de Ciências e Tecnologia, Universidade Estadual Paulista - FCT/UNESP, Presidente Prudente, Brasil

\begin{abstract}
This study aims to evaluate the degradation of façades with mortar coating as a finish, inspecting 22 residential buildings in Fernandópolis-SP, Brazil. The building defects (BD) were quantified considering the solar orientation of the façades and an evaluation of five typified façade regions: continuous walls (1-OCW); around openings (2-OOP); top of the parapets/eaves (3-TOP); below balconies, soffits or ledges (4-BCP); and on corners and edges (5-OCE). In addition, for the degradation assessment, five levels of degradation were considered, ranging from 0 (no degradation) to 4 (highest degradation). The highest number of BDs was observed for façades with an east solar orientation, and the general degradation levels observed were 1-OCW (3.21/3.00), 2OOP (2.88/2.82), 3-TOP (2.97/2.89), 4-BCP (3.04/2.78) and 5-OCE (2.56/2.54).
\end{abstract}

Keywords: Mortar Render; Anomalies; Degradation of Facades; Building Pathology; Degradation level.

\section{RESUMO}


Este trabalho objetivou avaliar a degradação das fachadas com revestimento argamassado como acabamento, inspecionando 22 edifícios residenciais em Fernandópolis-SP, Brasil. Para avaliação da degradação foi considerado 5 níveis de degradação, variando de 0 (nenhuma degradação) a 4 (degradação muito acentuada), a quantificação de manifestações patológicas (MP) por 2 métodos distintos, a orientação solar das fachadas, bem como a avaliação de 5 regiões tipificadas de fachada: 1-paredes contínuas (OCW), 2-entorno de aberturas (OOP), 3-topo de parapeitos e beirais (TOP), 4-abaixo de varandas/sacadas/ressaltos (BCP) e 5-cantos/bordos (OCE). A maior quantidade de MP foi observada para as fachadas com orientação solar Leste, sendo que os níveis de degradação gerais observado foram: 1-OCW $(3,21 / 3,00), 2-O O P(2,88 / 2,82)$, 3-TOP $(2,97 / 2,89), 4-\mathrm{BCP}(3,04 / 2,78)$ e 5 -OCE $(2,56 / 2,54)$.

Palavras chave: Revestimentos de Argamassa; Anomalias; Degradação das Fachadas; Patologia das Edificações; Nível de Degradação.

\section{RESUMEN}

Este trabajo tuvo como objetivo evaluar la degradación de fachadas con revestimiento de mortero como acabado, inspeccionando 22 edificios residenciales en Fernandópolis-SP, Brasil. Para evaluar la degradación se consideraron 5 niveles de degradación, que van desde 0 (sin degradación) a 4 (degradación muy severa), la cuantificación de manifestaciones patológicas (PM) por 2 métodos diferentes, la orientación solar de las fachadas, así como la evaluación de 5 regiones típicas de fachadas: 1-muros continuos (OCW), entorno de 2 aberturas (OOP), 3-top de parapetos y aleros (TOP), 4-debajo de balcones / balcones / proyecciones (BCP) y 5-esquinas / bordes (OCE). La mayor cantidad de PM se observó para las fachadas con orientación solar este, y los niveles generales de degradación observados fueron: 1-OCW (3.21/3.00), 2-OOP (2.88 / 2.82), 3-TOP (2.97 / 2.89), 4-BCP (3.04 / 2.78) y 5-OCE (2.56/2.54).

Palabras clave: Recubrimientos de mortero; Anomalías; Degradación de Fachadas; Patología de la edificación; Nivel de degradación.

\section{INTRODUCTION}


The external mortar render (EMR) represents the first layer for protection against environmental agents; it must therefore be an element that meets the minimum or basic requirements aimed at an acceptable level of performance and fulfillment of a useful life (SILVA et al., 2013).

The various factors that affect the durability of buildings and their subsystems, such as the EMR, can be subdivided into two categories: The first is related to the durability of the system, and the second is related to the aggressiveness of the environment (SOUZA et al., 2018). Lee (2021) emphasized that the building facade is affected throughout its useful life, highlighting the environmental effects and physical performance of the materials that make up the render system.

In Brazil, there is a preponderance in the use of a mortar rendering façade as a finish for building façades, which is easily justified by the low cost when compared to other types of cladding, as well as by the existing culture, which is clearly based on the Portuguese tradition (SILVA, 2007). Despite the preponderance of EMR as a final lining, little attention has been paid to technological control, which is associated with the lack of adequate technical knowledge in the manufacture of mortars, often causing the appearance of building defects (BDs) that compromise the function of the coating (STOLZ and MASUERO, 2015).

Thus, VANDERMARK et. al (2021) mentioned that it is necessary to coordinate several issues between professionals so that the design and construction achieve the goals. This coordination must, in fact, represent a compatibility between performance, quality, durability and aesthetics in the facade, placing the same weight for each item. The presence of BDs causes a decline in the functional performance of the EMR, frustrating the protection with environmental agents and adding, as a rule, additional damage to the user of symbolic and esthetic origin, motivated by the degradation of the building and its components (DORFMAN and PETRUCCI, 1989).

The BDs that affect the EMR often have several origins, highlighting the causes for design failures, owing to a lack of adequate knowledge regarding the characteristics of the materials used and/or the use of inappropriate materials, resulting from execution errors resulting from the absence of effective or proper maintenance. Although it is a minor problem if treated in isolation, once it acts at the limit, it becomes a preponderant and generates a pathological case (BAUER, 2017).

Therefore, the lack of knowledge of professionals in the production chain also causes failures, and projects often specify solutions that do not provide adequate results in practice (FREITAS, 2012). Although the topic is of great complexity in view of the numerous problems that affect the EMR, there is insufficient information about cases and problems available to help designers and builders in decision making (VANDEMARK et. al, 2021).

In this context, the absence of concise data on the origin of pathological problems, the most common forms of such manifestation, and the lack of registration and dissemination of data, delay the development and improvement of the techniques of design and construction, potentially harming younger professionals in the building construction chain, and thus do not prevent repeated errors that have already occurred in the past (THOMAZ, 2020).

In the last several studies have been developed for the creation of methodologies to predict the useful life, performance and repair techniques of the EMR, but for its application field information about the available problems is required (VIEIRA et al., 2015; CARVALHO et al., 2016; SILVA et al., 2018; CHARISI et al., 2018; SOUZA et al., 2018; FERREIRA et al., 2019; ANSAH et al., 2020; SAVIZ et al., 2020; PEREIRA et al., 2021; KHAN and BHATTACHARJEE, 2021).

Thus, Maciel and Carvalho (2019) cited that external cladding construction systems need to be evaluated in different regions because the climate is quite varied. Fabbri et al. (2020) highlighted the effects of solar radiation on the vertical and horizontal surfaces of a building and reported a greater focus on esthetic aspects, neglecting the issues related to the required performance.

In addition to climatic actions, the types of action of degradation agents, as well as the cycles of action, solar orientation, peculiarities of design and execution, and the conditions of the neighborhood can result in different performances for façades of the same building (CERQUEIRA, 
2018). Given the significant relevance of the theme, it is important to study the degradation of the façades of buildings and the pathological manifestations that will act throughout their lifetime, which tend to be minimized when duly foreseen during the design or execution of the coating (POSTINGHER et al., 2019).

Thus, this study aims to assess the degradation of the façades of residential buildings in Fernandópolis-SP, Brazil, using qualitative parameters, in addition to observing the main manifestations that affect these buildings.

\section{Case study}

\subsection{Sampling}

A total of 22 residential buildings with more than 5 floors located in the city of Fernandópolis-SP were studied. No statistical method was applied for the choice of buildings because all buildings that fit this prerequisite (more than five floors and residential use) were studied. These buildings have a predominantly rectangular floor plan, with no important internal façades. A total of 88 façades were applied.

\subsection{Inspection / Data collection}

For data collection, an inspection procedure was adopted as reported by Antunes (2010), with the inspection conducted from right to left, from top to bottom, and floor by floor. The adoption of standardized procedures aims to ensure that all field data are duly noted and standardized. The collected data refer exclusively to the EMR. In the presence of decorative elements and/or coatings other than the EMR, even in the presence of pathological manifestations, these were not considered. Field information was recorded on an inspection form developed for this research, as highlighted in Figure 1.

\subsection{Observed BDs}

In this study, the main BDs affecting multi-story residential buildings in the municipality were addressed. The BDs evaluated were horizontal crack (HC), vertical crack (VC), leaning crack (LC), mapped crack (MC), detachment with blistering (BD), detachment in plates (PD), powderiness detachment (WD), vesicles (VS), light stains (LS), dark stains (DS), and fantomes (FA). When other types of BD were found in the EMR, they were assigned a designation (OT).

\subsection{BDs Location}

To define the location of the BDs, they were considered in five typified regions of the façade: (1) on continuous walls (OCW), (2) around openings (OOP), (3) on top of parapets and eaves (TOP), (4) below balconies or ledges (BCP), and (5) in the corners and edges (OCE), as shown in Figure 2.

\subsection{BDs quantification}

Quantification of the BDs was conducted by considering two different methods of quantification: incidence and intensity. In the intensity method (M-INT), the objective is to evaluate the frequency of the BDs, and thus all MPs are quantified, regardless of the number of repetitions. In the incidence method (M-INC), the objective is to assess the recurrence of problems, and each BD is quantified only once per façade and location. The importance of evaluating the quantity in two methods of quantification occurs because, in terms of intensity, problems can be increased because of their repetitions, where the recurrence is more significant. Otherwise, it also matters because the potentialization of problems (number of repetitions) usually indicates localized problems, which also deserve attention. 


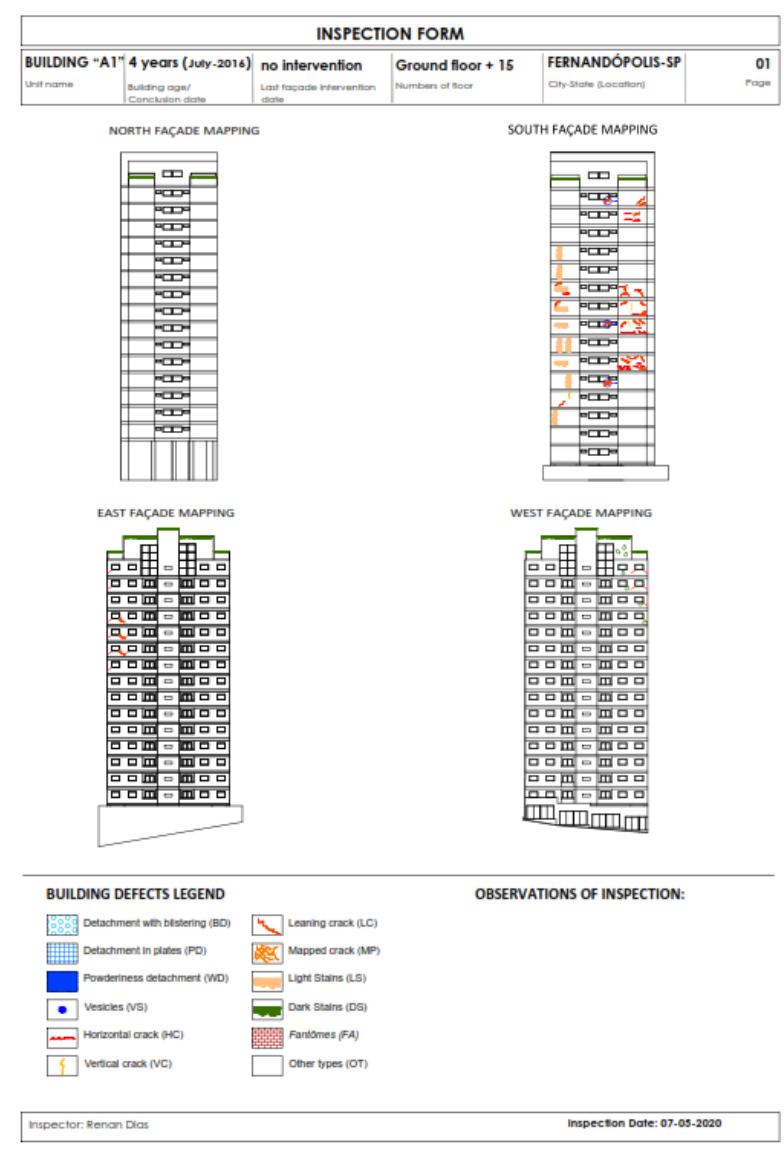

Figure 1. Inspection Form

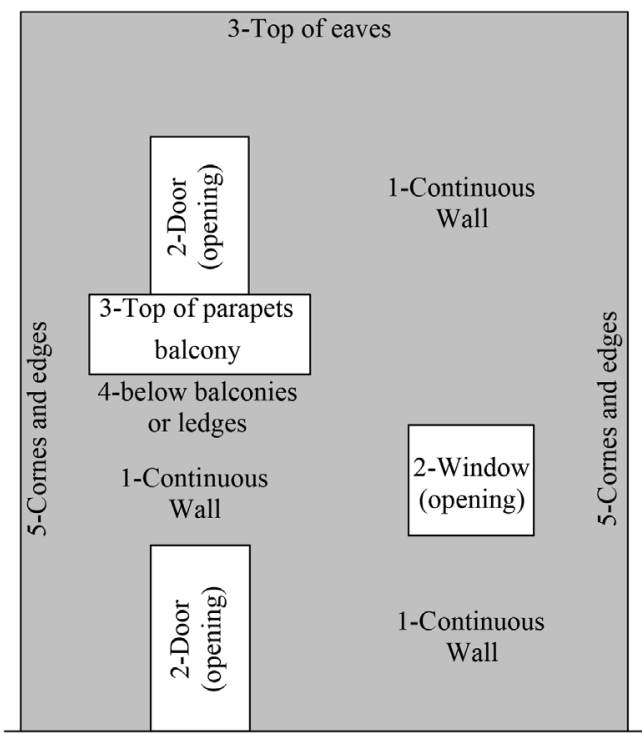

Figure 2. Typified regions of the facade

Source: Gaspar and Brito (2005) modified by the Author

\section{FAÇADE DEGRADATION}

\subsection{Degradation level}

The degradation level (DL) is commonly defined based on qualitative parameters, which implies a sensory analysis of the conservation status of the property. In the present case study, the levels of degradation were subdivided into five levels, ranging from level 0 (no degradation) to level 4 (highest degradation), as shown in Table 1.

\subsection{General degradation level}

With the DL for each defined BD, it is possible to determine the level of general degradation for each typified region of the facade. For this purpose, the expression determined by Equation (1) is used, which basically consists of the arithmetic mean of multiplying the amount of MP by its corresponding level of degradation, by facade and location.

$$
D L_{(R, \mathrm{IT})}=\frac{\sum B D_{R, \mathrm{IT}} \cdot D L_{\mathrm{BD}, R, I T}}{\sum B D_{G, I T}} \text { ou } D L_{(R, \mathrm{IC})}=\frac{\sum B D_{R, \mathrm{IC}} \cdot D L_{\mathrm{BD}, R, I C}}{\sum B D_{G, I C}}
$$

where $\mathrm{DL}_{(\mathrm{R})}$ denotes each typified region $\mathrm{DL}$ (ranging from $0=$ no degradation to $4=$ the highest degradation);

$\mathrm{BD}_{\mathrm{R}}$ denotes the amount of $\mathrm{BD}$ that occurs in region $\mathrm{R}$ for each quantification method;

$\mathrm{DL}_{\mathrm{BD}, \mathrm{R}}$ corresponds to the specific DL of BD;

$\mathrm{MP}_{\mathrm{G}}$ represents all $\mathrm{BDs}$ able to represent the sum of each specific orientation or the total solar 
orientation, as the case may be;

and IC and IT correspond to the methods of quantifying BD, that is, M-INC and M-INT, respectively.

Table 1. Degradation Levels

\begin{tabular}{|c|c|c|}
\hline Degradation Level & Visual defects observed & Strategic action \\
\hline $\begin{array}{l}\text { Level } 0 \text { - No } \\
\text { degradation (desirable } \\
\text { situation) }\end{array}$ & $>$ No visual degradation was observed & Does not require attention \\
\hline $\begin{array}{l}\text { Level } 1 \text { - Very mild } \\
\text { degradation sinals } \\
\text { (suitable condition) }\end{array}$ & $\begin{array}{l}\text { Leve Light superficial staining, without the presence of } \\
\text { efflorescences }\end{array}$ & Periodic visual assessment \\
\hline $\begin{array}{l}\text { Level } 2 \text { - Mild } \\
\text { degradation sinals } \\
\text { (acceptable condition) }\end{array}$ & $\begin{array}{l}\text { Linear cracks (vertical, horizontal or linear) isolated or } \\
\text { widely spaced, with few repetitions along the facade } \\
\text { Accentuated surface staining, with mild signs of } \\
\text { efflorescence or presence of moisture }\end{array}$ & $\begin{array}{l}\text { Surface cleaning by } \\
\text { brushing and washing }\end{array}$ \\
\hline $\begin{array}{l}\text { Level } 3 \text { - Wide } \\
\text { degradation (minimum } \\
\text { acceptable condition) }\end{array}$ & $\begin{array}{l}\text { Intense linear cracks (vertical, horizontal or inclined), } \\
\text { occurring in several parts, but spaced apart } \\
>\quad \text { Isolated mapped cracks } \\
>\quad \text { Lamaged corners or edges } \\
>\quad \text { Light stains (efflorescences) } \\
>\quad \text { Fantomes } \\
>\quad \text { Alteration of tonality and surface texture }\end{array}$ & Repair and protection \\
\hline $\begin{array}{l}\text { Level } 4 \text { - Very severe } \\
\text { degradation (worst } \\
\text { condition / not } \\
\text { acceptable) }\end{array}$ & $\begin{array}{l}>\text { Linear cracks very intense and not widely spaced } \\
\text { (agglomerated) } \\
>\quad \text { Mapped cracks agglomerated or with many repetitions } \\
>\text { Detachments } \\
>\text { Vesicles }\end{array}$ & $\begin{array}{l}\text { Partial or complete } \\
\text { replacement of the } \\
\text { damaged element }\end{array}$ \\
\hline
\end{tabular}

Source: Gaspar and Brito (2005) - modified by the Author

\section{RESULTS}

\subsection{Local climate}

In addition to the survey of BDs and their degradation, the local climate was assessed according to the events that occurred from January 2015 to January 2020, based on a consultation with the database of the Integrated Center for Agrometeorological Information (CIIAGRO) and the Brazilian Agency of Meteorology (CLIMATEMPO). Figures 3-4 show the local climatic conditions.

Based on the events of the analyzed period, a typical seasonality can be established, featuring a period with a hot and humid climate and a cold and dry climate. This statement confirms the classification of type Aw (savanna climate) according to the global system of Köppen-Geiger climate types. In addition, another factor that stands out is related to the local winds, which are perceived regardless of the speed, with full predominance in the directions combined with the cardinal direction East (E) and practical nonexistence in the other directions.

\subsection{Predominance of BDs by solar orientation}

Regarding the M-INC, the East and North façades were those with the most problems, followed by the South and West façades with practically the same quantity and percentage. In the study carried out by Mazer et al. (2013), the problems were predominant in the north and west façades, followed by the east and south façades. As for M-INT, the east and west façades were the most significant, followed by the north and south façades with practically the same quantity and percentage. In the study carried out by Antunes (2010), the distribution of the problems occurred in decreasing order 
on the north, south, west, and east façades, whereas Consoli (2006) observed a greater occurrence on the south façade, followed by the east, west, and north façades. Next, Table 2 presents the results and comparisons between different studies.

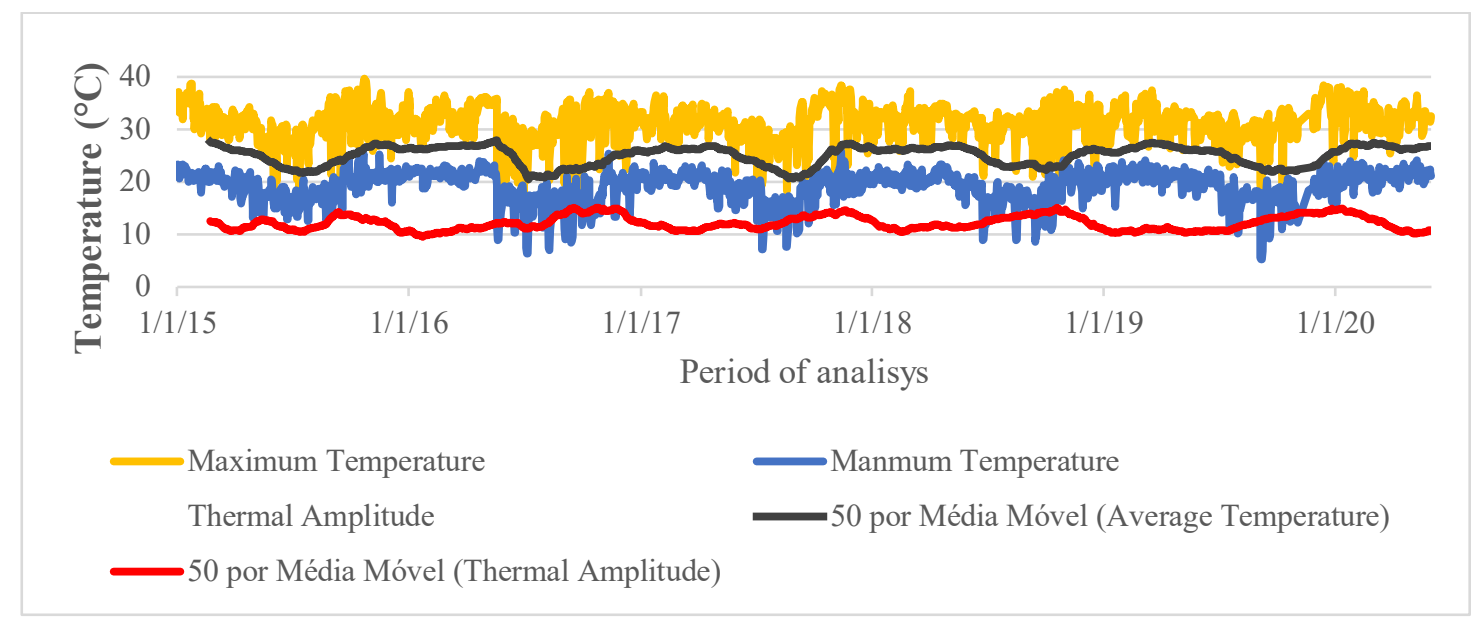

Figure 3. Thermal amplitude and temperature variation Source: CIIAGRO - adapted by the Author
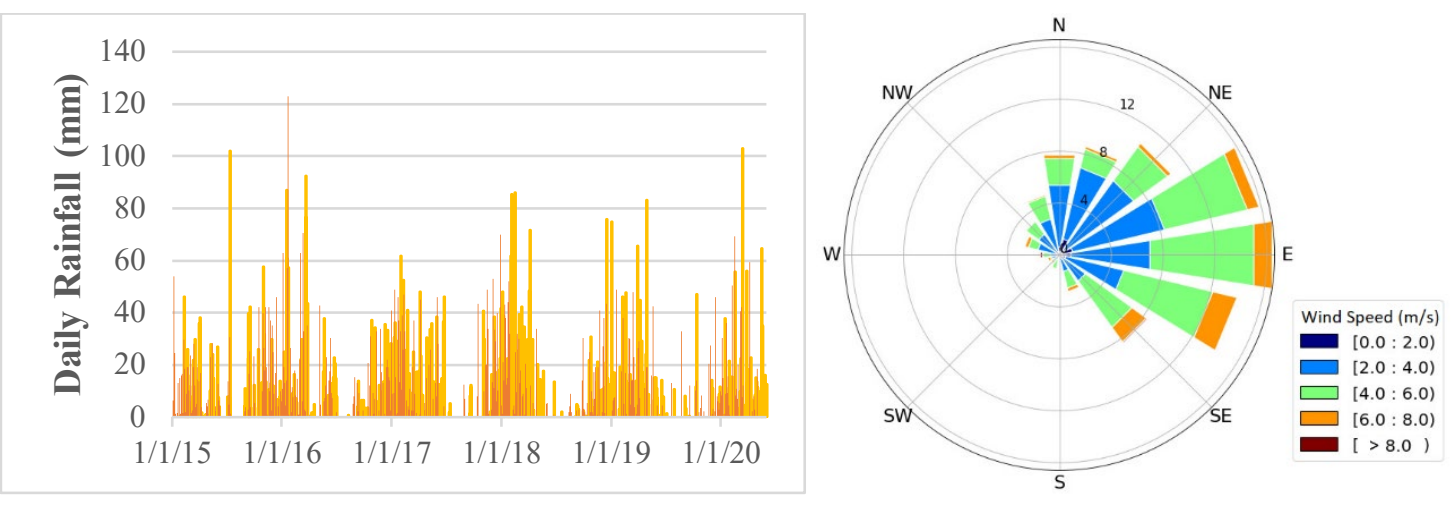

Figure 4. Left-Precipitation / Right-Predominant winds and speeds Source: CIIAGRO / CLIMATEMPO - adapted by the Author

\subsection{Typified regions degradation}

Figures 5-23 show the occurrence or frequency of each type of BD based on solar orientation and region, as well as the DLs of each region and solar orientation, for M-INC and M-INT. In the aforementioned figures, it is possible to observe for each type of BD its percentage of occurrence, as well as its corresponding average DL. The general percentage of occurrence of BD and the level of degradation of each region and method are shown in Table 3, in which the levels of degradation mentioned are the most frequent, in decreasing order. In addition, Table 4 presents the DL for each typified region by BD and the quantification method.

In Region 1, with continuous walls (Figures 5-8), although there is less repetition of pathological problems compared to Region 2, these anomalies are much more important because their level of degradation is greater, which was also verified by Gaspar and Brito (2005), Antunes (2010), and Souza et al. (2019). This occurs because there was a predominance of cracks and detachments in this region, which represent the BDs with the greatest aggressive potential, notably represented by higher levels of degradation (level 4). It is possible to notice even greater degradation potential in M-INT than in M-INC, given the fact of considering the frequency and recurrence of BDs, 
respectively. It is also recorded that all types of cracks were found, with a higher occurrence of horizontal cracks, followed by the mapped cracks, which give Region 1 the highest level of degradation for both methods of quantification.

Table 2. Results comparison

\begin{tabular}{|c|c|c|c|c|c|c|c|}
\hline \multicolumn{7}{|c|}{ M-INC } \\
\hline $\begin{array}{c}\text { Autor } \\
\text { (Year) }\end{array}$ & $\begin{array}{c}\text { Local or } \\
\text { Region }\end{array}$ & Climate & Characteristic & N (\%) & S (\%) & E (\%) & W (\%) \\
\hline $\begin{array}{c}\text { Dias et } \\
\text { al. } \\
(2021)\end{array}$ & $\begin{array}{c}\text { Fernandópolis- } \\
\text { SP, Brazil }\end{array}$ & $\begin{array}{c}\text { Savanna climate - } \\
\text { Aw }\end{array}$ & $\begin{array}{c}\text { Dryer season in } \\
\text { winter and wetter in } \\
\text { summer }\end{array}$ & $24,74 \%$ & $23,28 \%$ & $28,90 \%$ & $23,08 \%$ \\
\hline $\begin{array}{c}\text { Mazer } \\
\text { et al. } \\
(2013)\end{array}$ & $\begin{array}{c}\text { Curitiba-PR, } \\
\text { Brazil }\end{array}$ & $\begin{array}{c}\text { Temperate oceanic } \\
\text { climate - Cfb }\end{array}$ & $\begin{array}{c}\text { No dry season and } \\
\text { cool summer }\end{array}$ & $36,76 \%$ & $17,65 \%$ & $23,53 \%$ & $27,94 \%$ \\
\hline $\begin{array}{c}\text { Author } \\
\text { (Year) }\end{array}$ & $\begin{array}{c}\text { Local or } \\
\text { Region }\end{array}$ & Climate & M-INT & Characteristic \\
\hline $\begin{array}{c}\text { Dias et } \\
\text { al. } \\
(2021)\end{array}$ & $\begin{array}{c}\text { Fernandópolis } \\
\text {-SP, Brazil }\end{array}$ & $\begin{array}{c}\text { Savanna climate - } \\
\text { Aw }\end{array}$ & $\begin{array}{c}\text { Dryer season in } \\
\text { winter and wetter in } \\
\text { summer }\end{array}$ & $21,12 \%$ & $\mathbf{S ~ ( \% )}$ & $\mathbf{E ~ ( \% ) ~}$ & $\mathbf{W}(\mathbf{\%})$ \\
\hline $\begin{array}{c}\text { Consoli } \\
(2006)\end{array}$ & $\begin{array}{c}\text { Pato Branco- } \\
\text { PR, Brazil }\end{array}$ & $\begin{array}{c}\text { Humid subtropical } \\
\text { climate - Cfa }\end{array}$ & $\begin{array}{c}\text { No dry season and } \\
\text { hot summer }\end{array}$ & $21,00 \%$ & $32,06 \%$ & $25,74 \%$ \\
\hline $\begin{array}{c}\text { Antunes } \\
(2010)\end{array}$ & $\begin{array}{c}\text { Brasília-DF, } \\
\text { Brazil }\end{array}$ & $\begin{array}{c}\text { Savanna climate - } \\
\text { Aw }\end{array}$ & $\begin{array}{c}\text { Dryer season in } \\
\text { winter and wetter in } \\
\text { summer }\end{array}$ & $35,87 \%$ & $33,37 \%$ & $13,80 \%$ & $16,96 \%$ \\
\hline
\end{tabular}

Table 3. Percentage of BD occurrences by region and method

\begin{tabular}{|c|c|c|c|c|c|}
\hline \multirow{2}{*}{ Region } & \multirow{2}{*}{ BDs predominants } & \multicolumn{2}{|c|}{ M-INC } & \multicolumn{2}{c|}{ M-INT } \\
\cline { 3 - 6 } & & $\begin{array}{c}\text { BDsurrence } \\
\text { Occedominants } \\
\text { DLs of BDs }\end{array}$ & $\begin{array}{c}\text { Ocorrência } \\
\text { de BDs }\end{array}$ & $\begin{array}{c}\text { Predominants } \\
\text { DLs of BDs }\end{array}$ \\
\hline Region 1 & $\begin{array}{c}\text { Cracks and } \\
\text { detachments }\end{array}$ & $39,9 \%$ & 2,4 and 3 & $23,3 \%$ & 4,2 and 3 \\
\hline Region 2 & Stains and cracks & $16,6 \%$ & 2 and 4 & $34,5 \%$ & 2 and 4 \\
\hline Region 3 & $\begin{array}{c}\text { Stains, cracks and } \\
\text { detachments }\end{array}$ & $29,3 \%$ & 2 and 1 & $18,2 \%$ & 1 and 2 \\
\hline Region 4 & Stains and cracks & $6,4 \%$ & 2 and 4=1 & $21,6 \%$ & 2 and 4 \\
\hline Region 5 & $\begin{array}{c}\text { Cracks, stains and } \\
\text { some detachments }\end{array}$ & $7,7 \%$ & 2,3 and 1 & $2,4 \%$ & 2,1 and 3 \\
\hline
\end{tabular}

Table 4. Average DL for each Region, MP and General by Method

\begin{tabular}{|l|c|c|c|c|c|c|c|c|}
\hline \multirow{2}{*}{ Region } & \multicolumn{4}{|c|}{ DL/M-INT } & \multicolumn{4}{c|}{ DL/M-INC } \\
\cline { 2 - 10 } & Cracks & Stains & Detachments & General & Cracks & Stains & Detachments & General \\
\hline Region 1 & 2,94 & 2,50 & 4,00 & 3,21 & 2,44 & 2,41 & 4,00 & 3,00 \\
\hline Region 2 & 2,46 & 2,50 & 4,00 & 2,88 & 2,33 & 2,43 & 4,00 & 2,82 \\
\hline Region 3 & 2,25 & 2,32 & 4,00 & 2,97 & 2,17 & 2,09 & 4,00 & 2,89 \\
\hline Region 4 & 3,58 & 1,95 & No deg. obs. & 3,04 & 3,25 & 1,84 & No deg. obs. & 2,78 \\
\hline Region 5 & 2,12 & 2,00 & 4,00 & 2,56 & 2,09 & 2,00 & 4,00 & 2,54 \\
\hline
\end{tabular}

Associating problems with mechanisms, in these places there is a predisposition for greater hygrothermal movements both in the mortar of the EMR and in the laying of the masonry. In addition, in the presence of cracks, the facilitated open path for percolation/infiltration of moisture potentiates the formation of cracks and detachments. 
In addition, a predisposition to the formation of stains was noticed in the continuous walls of the eastern façade, which may be indicative of the effects of the associated wind and rain, in view of the predominance of winds in the cardinal regions combined with the east.

In Region 2, around the openings (Figures 9-12), high levels of stains were observed, followed by the formation of cracks. However, despite being the location with the highest frequency and recurrence of defects, most of them are level 2 defects, motivated by the large presence of stains, regardless of the quantification method used. Fissures were also found in several places, which stand out as the second most frequent PM in this region. In the presence of cracks, the level of degradation approached level 4 (the highest degradation), clearly noticeable in the figures cited, highlighting that although a high number of problems, the level of degradation is lower than in other regions, with the exception of Region 5, via M-INT. These observations were also made by Gaspar and Brito (2005).

Thus, it is clear that the architecture of the buildings studied and the windowsills of the openings do not faithfully fulfill their function, whether due to the probable deficiency in the installation and/or the probable absence of an appropriate drip pan. This condition may be a conditioning factor for the formation of runny dark spots in these regions. When observed, the cracks are predominantly linear (horizontal or inclined), commonly found in the openings owing to the concentration of effort and loads in the openings made possible by a probable deficiency (or even absence) of lintels and curves. In the presence of cracks, which are accompanied by moisture, the potential for damage in this region is high, and for this reason, some detachments and level 4 degradation are observed.

Also included in Region 2 are the openings for the installation of window-type air conditioners, in which the presence of many of these elements was observed on the studied façades, and in view of their relief on the façade cloth associated with the presence of the equipment itself, it is certainly a conditioning factor for the storage of atmospheric dust close to the wall (EMR). In addition, for psychometric reasons, these elements are water generators in a liquid state through condensation of water vapor from the atmospheric air, which must be drained into the rain network. The presence of too many stains below these elements indicates the insufficiency or even absence of drains for this equipment, which when splashing each other (because they are vertically aligned) forms a vertical wetting path from top to bottom by splashes or runoff water.

In Region 3, on top of parapets and eaves (Figures 13-16), there was a predominance of spots, followed by fissures and detachments. At least two of the three defects were at levels 1 and 2 of degradation, as observed by Gaspar and Brito (2005) and Freitas (2012), although diverging from the result obtained by Souza et al. (2019), where detachments are predominant. The level of degradation in this region is important as it tends to approach the minimum acceptable limit.

Commonly, the dark stains present in this region are manifested as a consequence of the directed rain and superficial water flow, which normally occurs owing to a failure or even absence of flashings or drips. The presence of moisture in this region owing to the aforementioned defects also contributes to the hygrothermal movement of the EMR and other components and may be the causative agent of cracks and detachments within this region.

Below the balconies, soffits, or ledges, that is, in Region 4 (Figures 17-20), stains and cracks prevailed, whose degradation patterns are extremely close to those in Region 2, as observed by Gaspar and Brito (2005), Antunes (2010), and Freitas (2012) . However, referring to the level of degradation, Gaspar and Brito (2005) observed greater degradation of levels 1 and 2, and in the current study, level 2 and 4 degradations were observed more frequently.

In general, the stains are classified as level 1 or 2 degradations, whereas the cracks are classified as level 2-4. Thus, as in the case of the South façade, a high recurrence of BDs of degradation level 4 raised the general level of degradation of that region. 
These façade regions have a particularity in relation to the others because they are usually reliefs or ridges, which contribute to the formation of a shaded region, even if it is a façade that is receiving incident sunlight. This condition generates, in a certain way, a protection of a certain area that, although it is the same base material and finish, has a temperature difference, and consequently there may be a differential movement of this element.

In addition, depending on the dimensions of these elements, the directed rain can reach the wall and form a superficial laminar flow of drained water, moistening the entire region slightly below the ridges. This factor associated with the protection of the area avoids a quick drying of the wall, and at this point, in addition to the differentiation of heating, there is also a difference in their moisture content, which is also a crack maker, notably observed with less incidence than the spots within this region.

In Region 5, the corners and edges of buildings (Figures 21-24), there was a predominance of cracks, followed by spots and detachments, as observed by Gaspar and Brito (2005) and with slight differentiation from Souza et al. (2019), who observed a predominance of detachments. It is the region with the lowest level of degradation, regardless of the method chosen.

In these regions, the joining of elements with different coefficients of thermal expansion is commonly observed, such as masonry and reinforced concrete structures. This combination of elements with different properties can be the motivators for the manifestation of fissures, as well as the concentration of efforts observed around the openings.

An easier path for the formation of stains is opened in the presence of cracks and moisture from the atmosphere. In addition, the structural and hygrothermal movements in the region can also contribute to cracking and detachment.

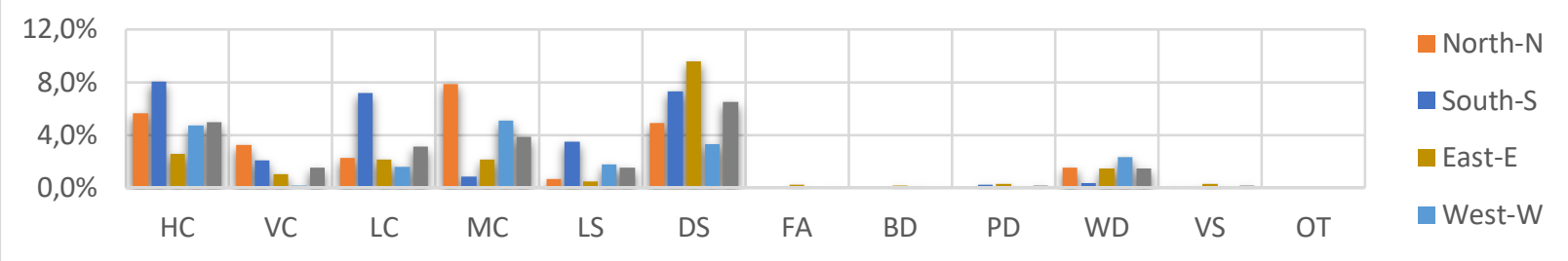

Figure 5. Frequency of BDs by solar and general orientation in Region 1 (OCW) - M-INT

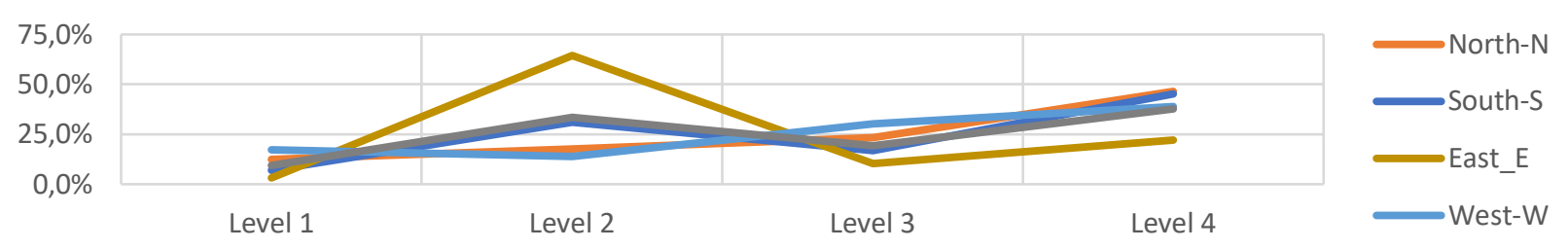

Figure 6. DL by solar and general orientation in Region 1 (OCW) - M-INT

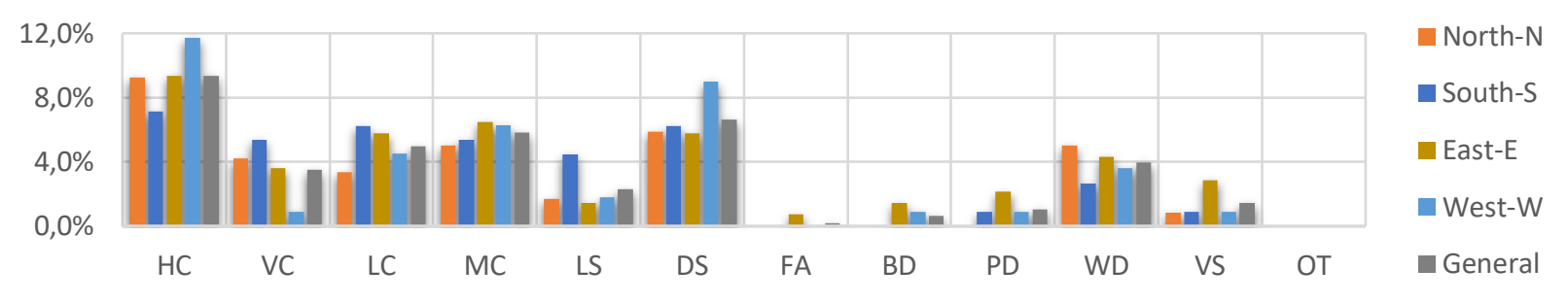

Figure 7. Occurrence of BDs by solar and general orientation in Region 1 (OCW) - M-INC

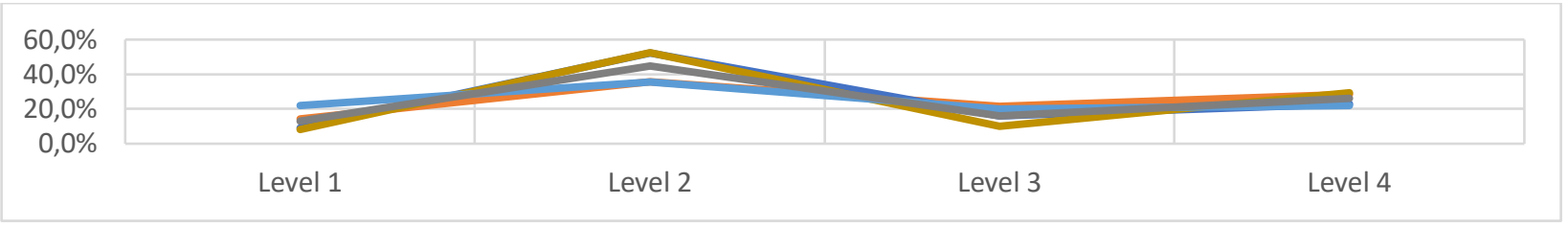


Figure 8. DL by solar and general orientation in Region 1 (OCW) - M-INC

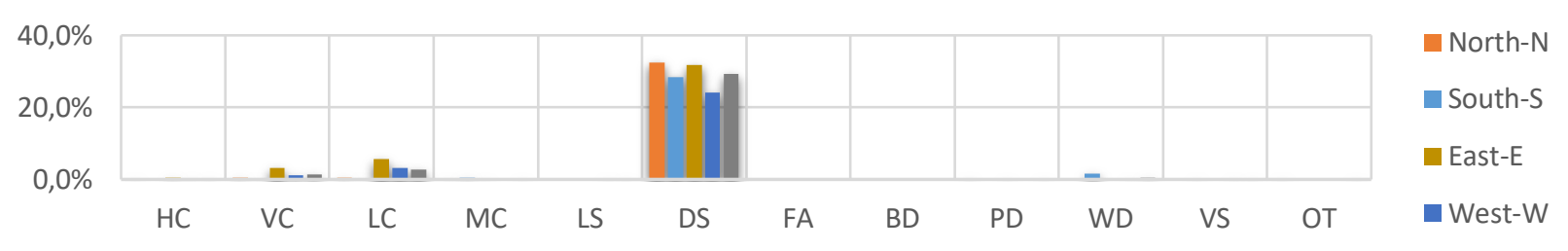

Figure 9. Frequency of BDs by solar and general orientation in Region 2 (OOP) - M-INT

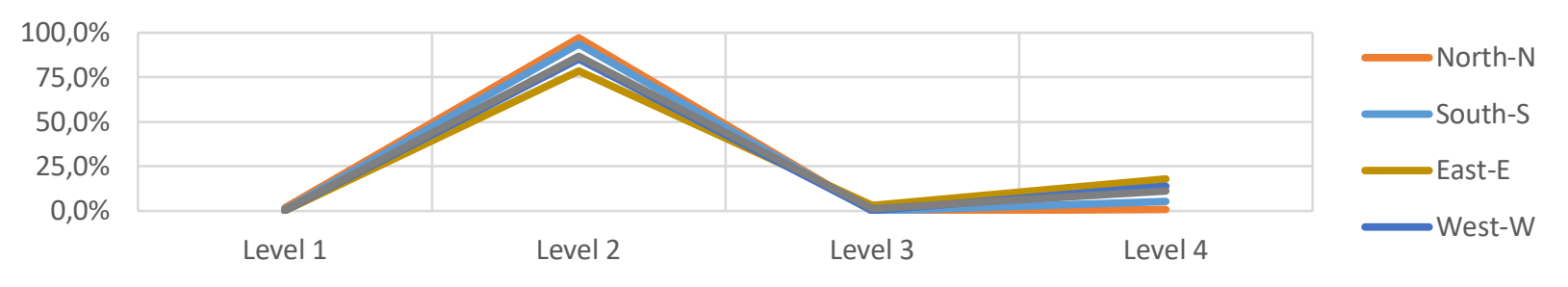

Figure 10. DL by solar and general orientation in Region 2 (OOP) - M-INT

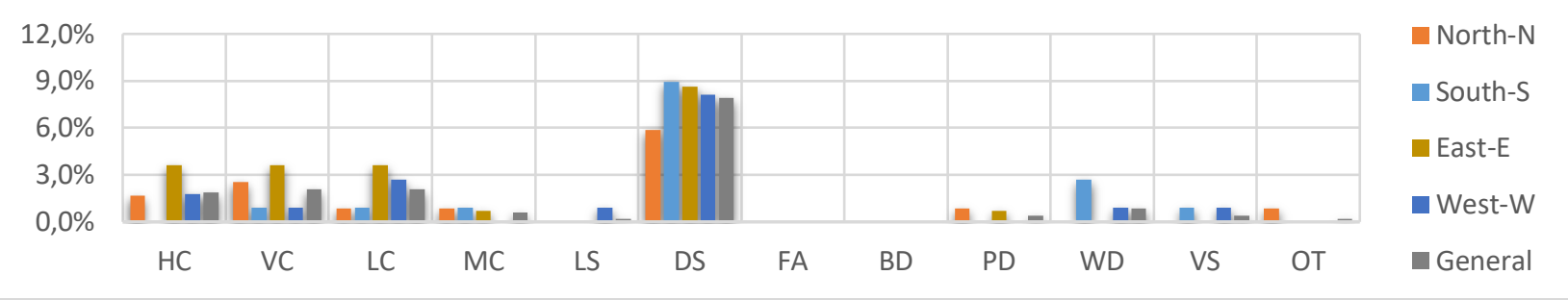

Figure 11. Occurrence of BDs by solar and general orientation in Region 2 (OOP) - M-INC

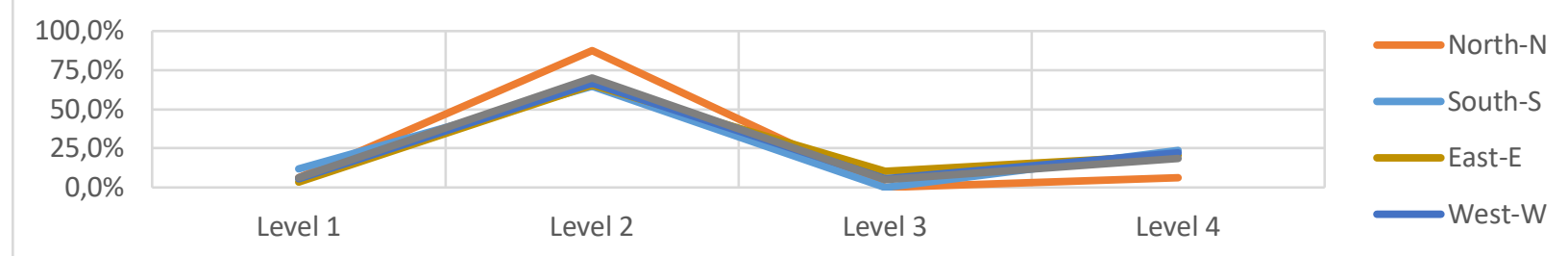

Figure 12. DL by solar and general orientation in Region 2 (OOP) - M-INC

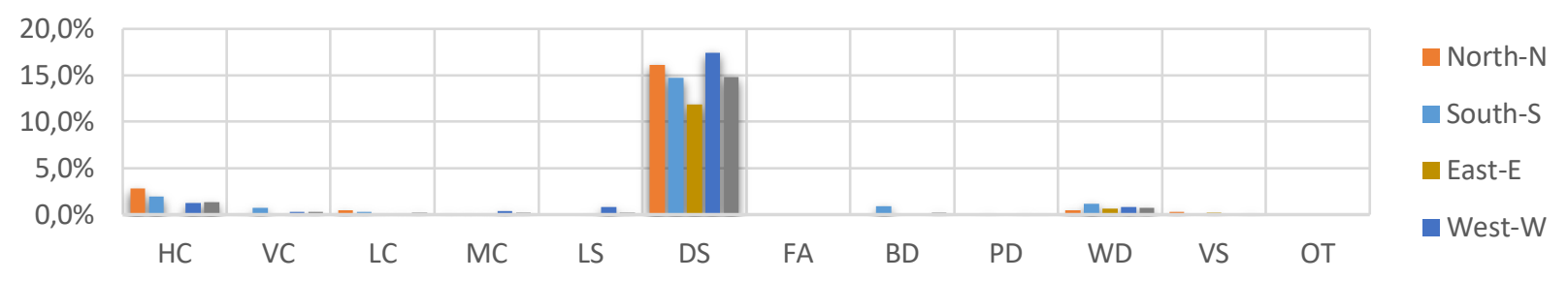

Figure 13. Frequency of BDs by solar and general orientation in Region 3 (TOP) - M-INT

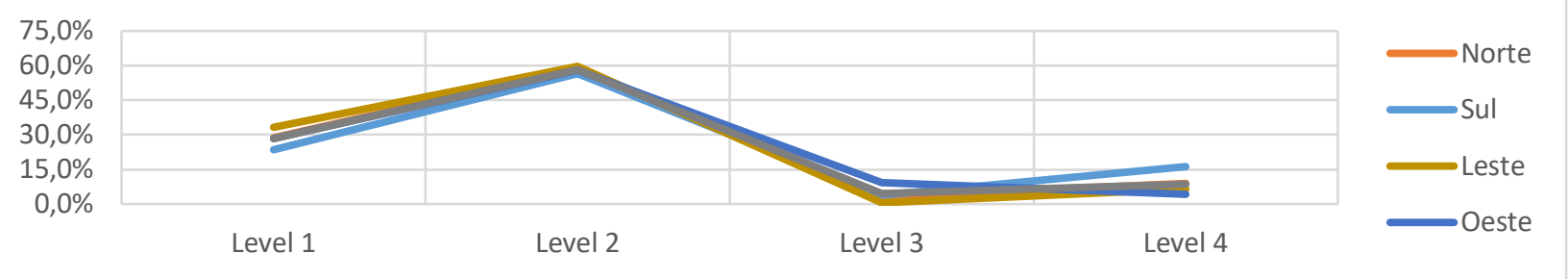

Figure 14. DL by solar and general orientation in Region 3 (TOP) - M-INT 


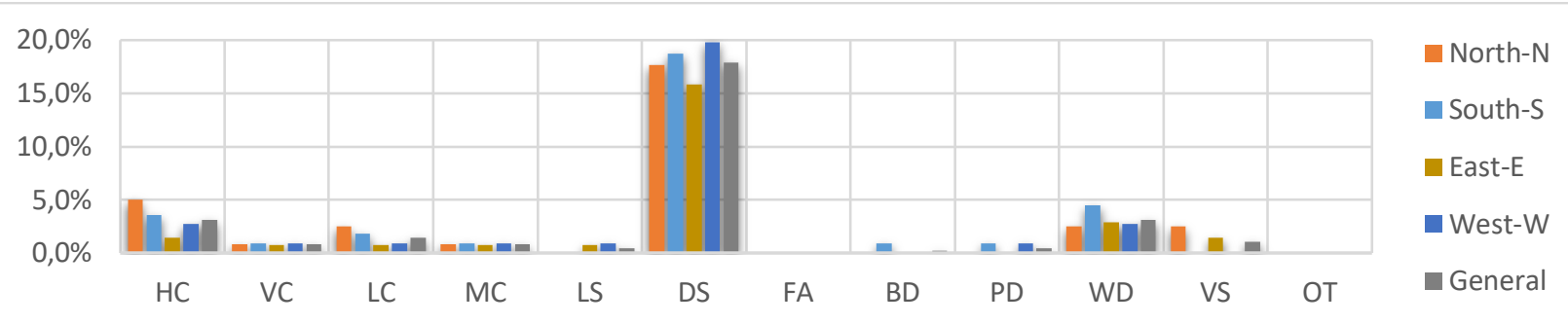

Figure 15. Occurrence of BDs by solar and general orientation in Region 3 (TOP) - M-INC

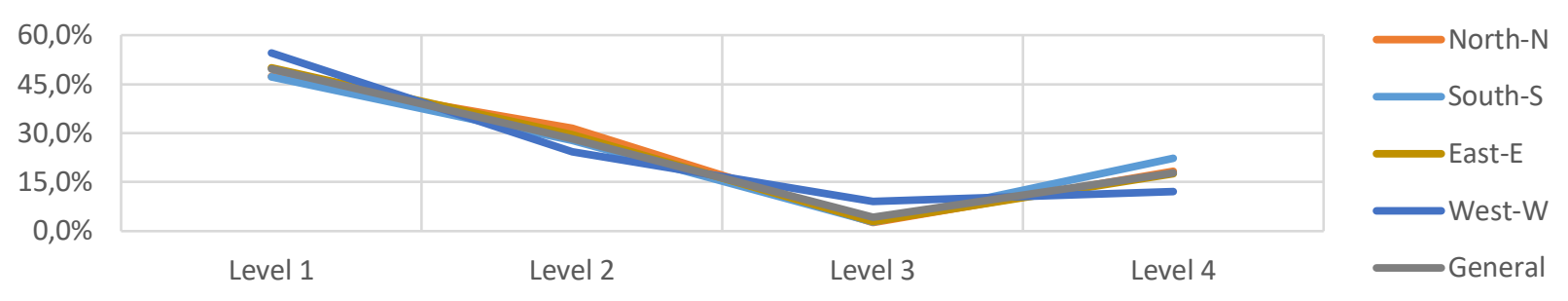

Figure 16. DL by solar and general orientation in Region 3 (TOP) - M-INC

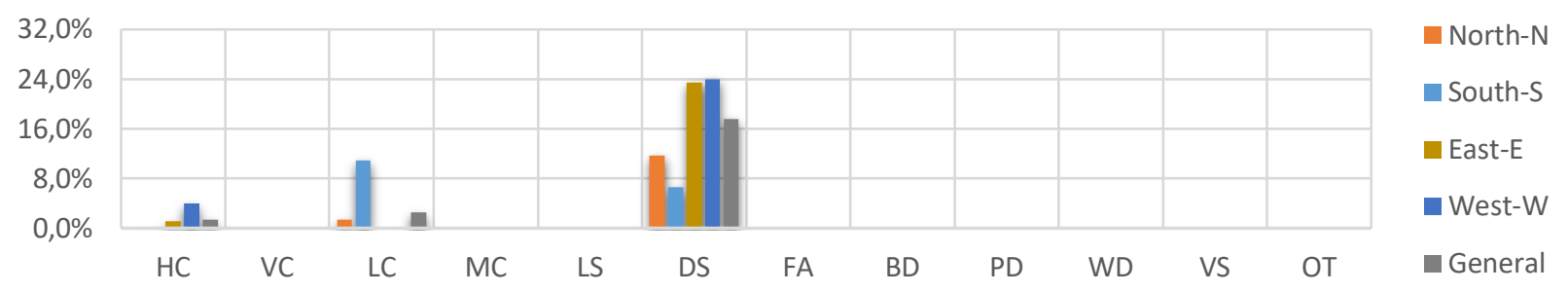

Figure 17. Frequency of BDs by solar and general orientation in Region 4 (BCP) - M-INT

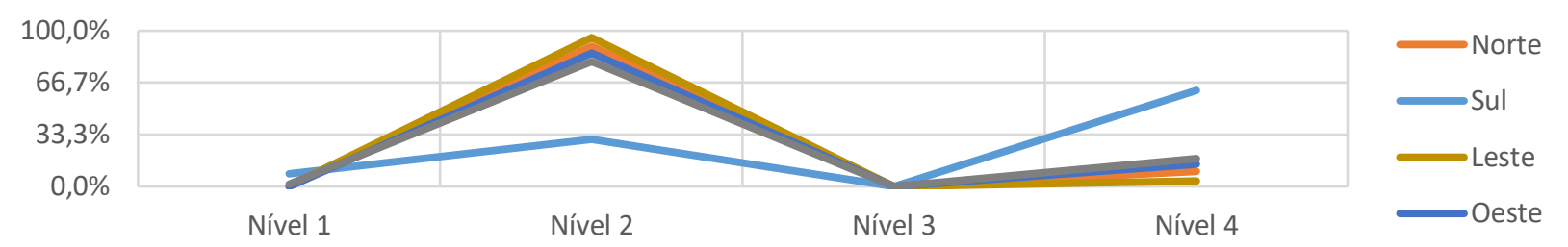

Figure 18. DL by solar and general orientation in Region 4 (BCP) - M-INT

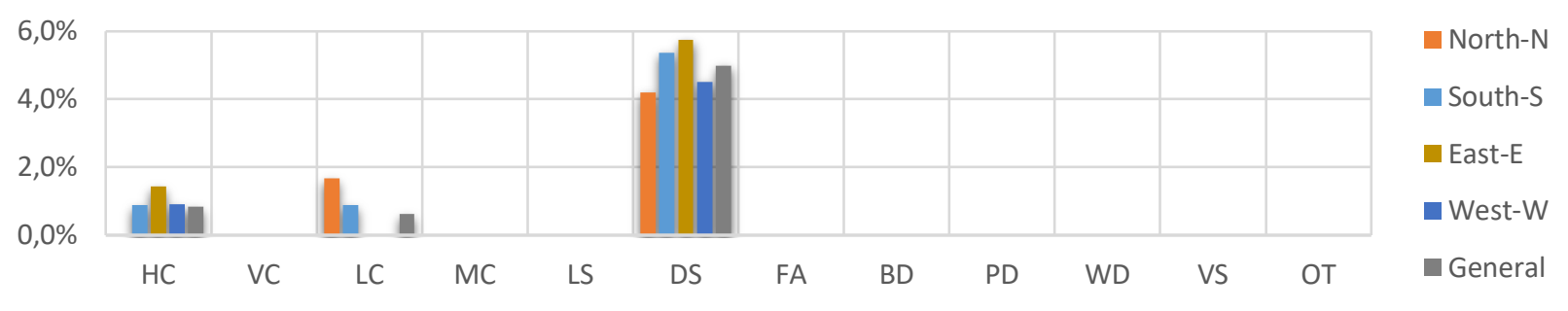

Figure 19. Occurrence of BDs by solar and general orientation in Region 4 (BCP) - M-INC

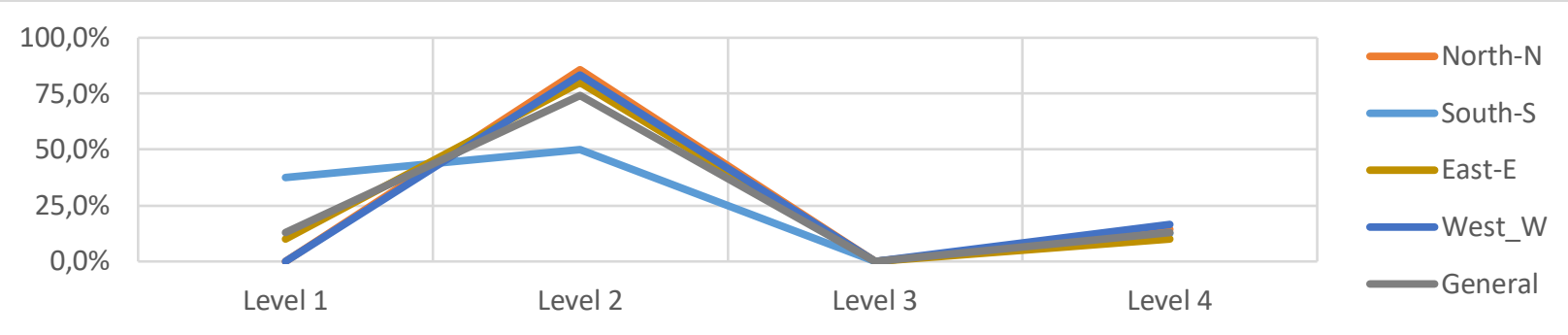

Figure 20. DL by solar and general orientation in Region 4 (BCP) - M-INC 


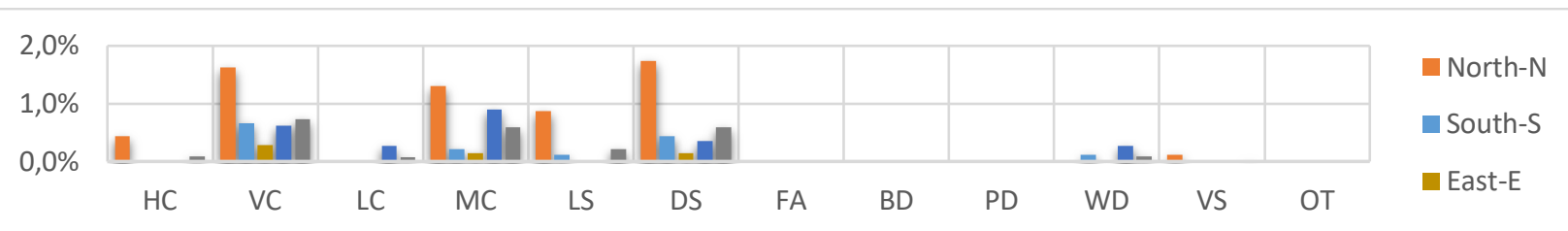

Figure 21. Frequency of BDs by solar and general orientation in Region 5 (OCE) - M-INT

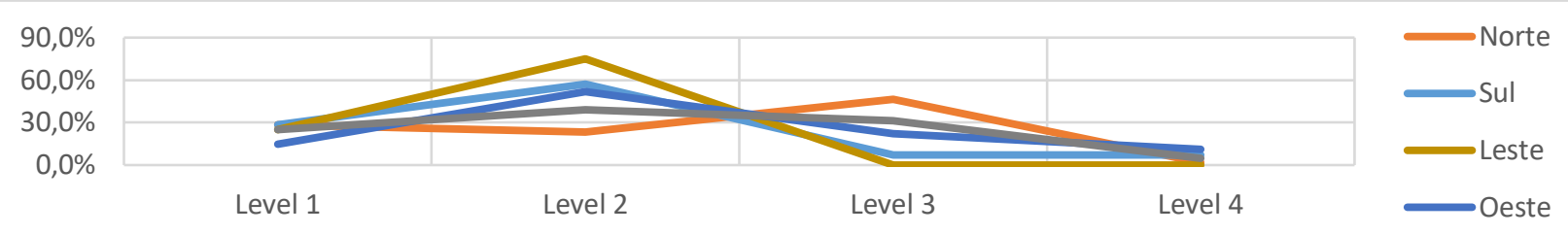

Figure 22. DL by solar and general orientation in Region 5 (OCE) - M-INT

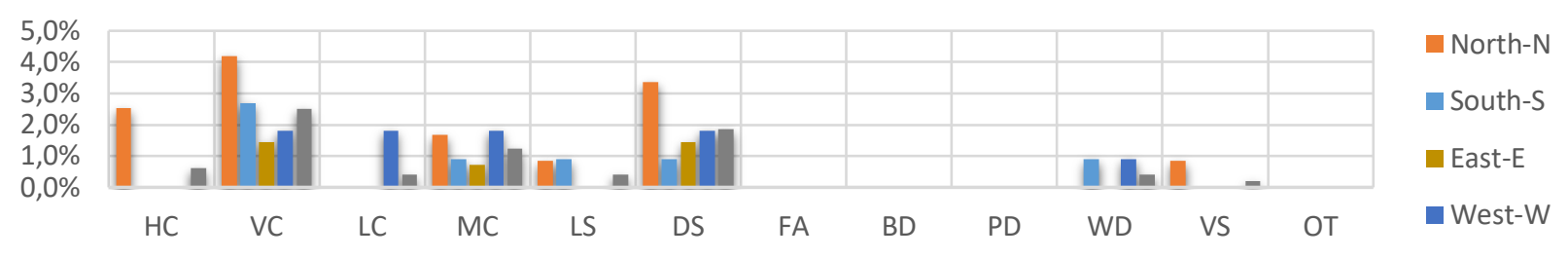

Figure 23. Occurrence of BDs by solar and general orientation in Region 5 (OCE) - M-INC

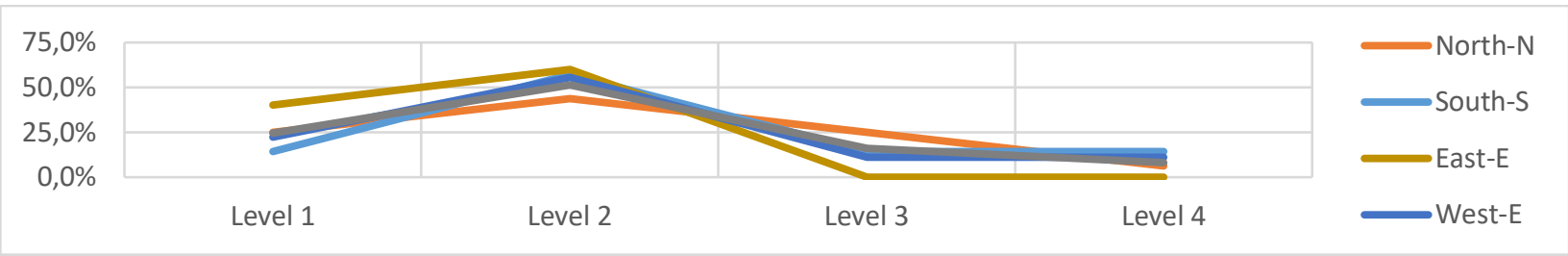

Figure 24. DL by solar and general orientation in Region 5 (OCE) - M-INC

\section{CONCLUSIONS}

Based on the results obtained, several conclusions could be verified, highlighting the parameters related to the local climate and the degradation of the façades. In addition, the way of quantifying and analyzing pathological problems considering recurrence and frequency allow a better reading of those MPs that occur with more repetitions.

It is also important to note that the more repetitions are considered, as these have specific DL, it is possible to notice a potentialization of the effects, clearly highlighting the points and regions with the greatest repetition of problems and/or the greatest level of degradation.

Regarding climate, this has two important peculiarities, namely, seasonality of the driest and rainiest periods, as well as the predominant wind direction for those combined with the eastern cardinal direction (E). Considering the recurrence and frequency of BDs observed by M-INC and M-INT, respectively, the following stand out:

- In Region 1, fissures and detachments were observed, with levels of degradation between 2 and 4, which were more recurrent than frequent.

- In Region 2, spots and fissures were observed, with levels of degradation between 2 and 4, which were more frequent than recurrent.

- In Region 3, spots, fissures, and detachments were observed, which were more recurrent than frequent.

- In Region 4, spots and fissures were observed, which were more frequent than recurrent. 
- In Region 5, cracks, spots, and detachments were observed, with more recurrence than frequency.

- Considering the M-INC, the most significant degradations are in Regions 1 (3.00) and Region 3 (2.89), followed by Region 2 (2.82), Region 4 (2.78), and Region 5 (2, 54), emphasizing that without considering the repetition of the problems, all regions of the façades are supposed to be under the minimum acceptable condition.

- For M-INT, the most significant degradations are in Region 1 (3.21) and Region 4 (3.04), followed by Region 3 (2.97), Region 2 (2.88), and Region 5 (2, 56), which highlight that, considering the repetition of the problems, there are two regions with a DL of above 3.00; therefore, they are more degraded than the minimum acceptable level.

\section{REFERENCES}

Ansah, M. K., Chen, X., Yang, H., Lu, L., Lam, P. T. I. (2020), An integrated life cycle assessment of different façade systems for a typical residential building in Ghana. Sustainable Cities and Society. 53:1-13. https://doi.org/10.1016/j.scs.2019.101974.

Antunes, G. R. (2010), "Estudo de manifestações patológicas em revestimentos de fachada de Brasília - Sistematização da incidência de casos”, Dissertação (Mestrado em Engenharia Civil), Faculdade de Tecnologia, Universidade de Brasília.

Bauer, L. A. F. (2017), “Materiais de Construção”. Volume 2. 5a ed. Revisada. LTC Editora. Rio de Janeiro. 538p.

Carvalho, C. G., Flores-Colen, I. e Faria, P. (2015), Rehabilitation of renders of old buildings in Portugal: Survey, supporting methodology proposal and case study. Structural Survey. 33(4/5):337-353. https://doi.org/10.1108/SS-04-2015-0024.

Cerqueira, M. B. S. (2018), "Avaliação da Degradação de Fachadas - Estudo de Caso em Salvador-BA”, Dissertação. Universidade Federal da Bahia, Escola Politécnica, Programa de PósGraduação em Engenharia Civil.

Charisi, S., Thiis, T. K., Stefansson, P., Burud, I. (2018), Prediction model of microclimatic surface conditions on building façades. Building and Environment. 128:46-54. https://doi.org/10.1016/j.buildenv.2017.11.017.

Consoli, O. J. (2006), "Análise da durabilidade dos componentes das fachadas de edificios sob a ótica do projeto arquitetônico”, Dissertação (Mestrado em Engenharia Civil), Programa de PósGraduação em Engenharia Civil, Universidade Federal de Santa Catarina.

Dorfman, G., Petrucci, H. M. C. (1989), "Recomendações para fachadas com vistas a sua maior durabilidade e facilidade de manutenção", Simpósio Sobre Patologia das Edificações, CPGEC/UFRGS, Porto Alegre: RS(BR), pp. 251-261.

Fabbri, K., Gaspari, J., Bartoletti, S., Antonini, E. (2020), Effect of facade reflectance on outdoor microclimate: An Italian case study. Sustainable Cities and Society. 54:1-12. https://doi.org/10.1016/j.scs.2019.101984.

Ferreira, C., Canhoto, L., Silva, A., Brito, J. (2019), Stochastic Petri-net models to predict the degradation of ceramic claddings. Building Research \& Information. 47(6):697-715. https://doi.org/10.1080/09613218.2018.1501873.

Freitas, J. G. (2012), “A influência das condições climáticas na durabilidade dos revestimentos de fachada: estudo de caso na cidade de Goiânia-GO”, Dissertação (Mestrado em Engenharia Civil), Escola de Engenharia Civil, Universidade Federal de Goiás.

Gaspar, P, Brito, J. (2005), Mapping defect sensitivity in external mortar renders. Construction and Building Materials. 19(8):571-578. https://doi.org/10.1016/j.conbuildmat.2005.01.014. 
Khan, N. A., Bhattacharjee, B. (2021), "Methodology for Simultaneous Optimization of the Thermal, Visual, and Acoustic Performance of Building Envelope”. Journal of Architectural Engineering. 27(3): 1-15. https://doi.org/10.1061/(ASCE)AE.1943-5568.0000474.

Lee, J. (2021), "Life Cycle Costing for Exterior Materials on Building Façade", Journal of Construction Engineering and Management. 147(7):1-11. https://doi.org/10.1061/(ASCE)CO.1943-7862.0002068.

Maciel, A. C. F., Carvalho, M. T. (2019), Operational energy of opaque ventilated façades in Brazil. Journal of Building Engineering. 25:1-10. https://doi.org/10.1016/j.jobe.2019.100775.

Mazer, W., Silva, L. M. R., Lucas, E., Santos, F. M. C. (2016), Evaluation of pathological manifestations in buildings in terms of geographical orientation. Revista ALCONPAT. 6(2):145156. https://doi.org/10.21041/ra.v6i2.135.

Pereira, C., Brito, J., Silvestre, J. D. (2021), "Harmonized Classification of Repair Techniques in a Global Inspection System: Proposed Methodology and Analysis of Fieldwork Data”. Journal of Performance of Constructed Facilities. 35(1): 1-16. https://doi.org/10.1061/(ASCE)CF.1943$\underline{5509.0001529 .}$.

Postingher, C. M., Kremer, B. M., Rossatto, F. C., Pacheco, F., Christ, R. (2019), “Avaliação das manifestações patológicas em revestimentos argamassados externos com VANT: estudo de caso em edificação multifamiliar do município de Garibaldi-RS”, XV Congreso Latinoamericano de Patología de Construcción y XVII Congreso de Control de Calidad en la Construcció, CONPAT. 2:1-15. https://doi.org/10.21041/CONPAT2019/V2PAT296.

Saviz, M., Luc E, C., Saeed, M. M. (2020), Design strategies using multi-criteria decision-making tools to enhance the performance of building façades. Journal of Building Engineering. 30:1-28. https://doi.org/10.1016/j.jobe.2020.101274.

Silva, A. F. (2007), "Manifestações patológicas em fachada com revestimentos argamassados. Estudo de Caso em edifícios em Florianópolis”, Dissertação (Mestrado em Arquitetura e Urbanismo), Universidade Federal de Santa Catarina.

Silva, A. Dias, J. L., Gaspar, P. L., Brito, J. (2013), Statistical models applied to service life prediction of rendered façades. Automation in Construction. 30:151-160. https://doi.org/10.1016/j.autcon.2012.11.028.

Silva, A., Brito, J, Gaspar, P. L. (2018), A comparative multi-criteria decision analysis of service life prediction methodologies for rendered façades. Journal of Building Engineering. 20:476-487. https://doi.org/10.1016/i.jobe.2018.08.009.

Souza, J. Silva A., Brito, J. Bauer, E. (2018), Service life prediction of ceramic tiling systems in Brasilia-Brazil using the factor method. Construction and Building Materials. 192:38-49. https://doi.org/10.1016/j.conbuildmat.2018.10.084.

Souza, J. S., Piazzarollo, C. B., Bauer, E. (2019), "Degradação nas diferentes zonas de fachadas em sistemas de revestimento", Simpósio Brasileiro de Tecnologia das Argamassas, XIII STBA, Goiania: GO(BR), pp. 136-144.

Stolz, C. M., Masuero, A. B. (2015), Analysis of main parameters affecting substrate-mortar contact area through tridimensional laser scanner. Journal of Colloid and Interface Science. 455:16-23. https://doi.org/10.1016/j.jcis.2015.05.028.

Thomaz, E. (2020), “Trincas em edifícios: causas, prevenção e recuperação”. 2. ed. $1^{\mathrm{a}}$ reimp. São Paulo, Ed. Oficina de Textos.

VanDemark, L., Clevenger, C. M., Click, M. (2021), "Building Envelope Issues within Construction-Defect Litigation”. Journal of Legal Affairs and Dispute Resolution in Engineering and Construction. 13(4): 1-20. https://doi.org/10.1061/(ASCE)LA.1943-4170.0000484.

Vieira, S. M., Silva, A., Sousa, J. M. C., Brito, J., Gaspar, P. L. (2015), Modelling the service life of rendered facades using fuzzy systems. Automation in Construction. 51:1-7. https://doi.org/10.1016/j.autcon.2014.12.011. 